\title{
Susceptibility of winter wheat cultivars to wheat ear insects in Central Germany
}

\author{
Nawal Gaafar · Christa Volkmar · Hilmar Cöster • \\ Joachim Spilke
}

Published online: 29 March 2011

(C) Springer-Verlag 2011

Erratum to: Gesunde Pflanzen (2011) 62:107-115

DOI 10.1007/s10343-010-0227-5

Unfortunately, the original version of this article has been published with an error in the German language abstract part.

Instead of (Halieus) it should read Haliday or (Hal.), as in the English abstract.

The online version of the article can be found under doi:10.1007/s10343-010-0227-5

N. Gaafar $(\bowtie) \cdot$ C. Volkmar $\cdot$ J. Spilke Institute of Agric. \& Nutritional Sciences,

Martin-Luther-University Halle-Wittenberg,

Betty-Heimann Str. 3, 06120 Halle (Saale), Germany

e-mail: nawal_gaafar@yahoo.com

H. Cöster

RAGT 2n, Steinesche 5a, 38855 Silstedt, Germany 